\title{
One cell, one love: a journal for microbial research
}

\author{
Didac Carmona-Gutierrez ${ }^{1, *}$, Guido Kroemer ${ }^{2-6}$ and Frank Madeo ${ }^{1, *}$ \\ ${ }^{1}$ Institute of Molecular Biosciences, University of Graz, Graz, Austria \\ ${ }^{2}$ INSERM, U848, Villejuif, France \\ ${ }^{3}$ Metabolomics Platform, Institut Gustave Roussy, Villejuif, France \\ ${ }^{4}$ Centre de Recherche des Cordeliers, Paris, France \\ ${ }^{5}$ Pôle de Biologie, Hôpital Européen Georges Pompidou, AP-HP, Paris, France \\ ${ }^{6}$ Université Paris Descartes, Paris 5, Paris, France \\ * Corresponding Authors: F. Madeo; E-mail: frank.madeo@uni-graz.at; and D. Carmona-Gutierrez; E-mail: carmonag@uni-graz.at
}

\section{INTRODUCTION}

With their broad utility for biotechnology, their continuous menace as infectious pathogens, and as an integral part of our bodies (intestinal flora), unicellular organisms remain in the focus of global research. This interest has been further stimulated by the challenge to counteract the emergence of multi-resistant microbes, as well as by the recent advances in establishing unicellular organisms as valid models for human diseases. It is our great pleasure to launch the inaugural issue of Microbial Cell (MIC), an international, open-access, peer-reviewed journal dedicated to microbial research. MIC is committed to the publication of articles that deal with the characterization of unicellular organisms (or multicellular microorganisms) in their response to internal and external stimuli and/or in the context of human health and disease. Thus, MIC covers heterogeneous topics in diverse areas ranging from microbial and general cell biology to molecular signaling, disease modeling and pathogen targeting. MIC's Editorial Board counts with world-class leaders in a wide variety of fields, including microbiology, aging, evolution, biotechnology, ecology, biochemistry, infection biology, and human pathophysiology. We are convinced that MIC will appeal to readers from a broad scientific and medical background, including basic researchers, microbiologists, clinicians, educators and - we hope - policy makers as well as to any interested individual.

\section{THE PAST, PRESENT AND FUTURE OF MICROBIAL RESEARCH}

Over the last decades microorganisms have been catapulted to the limelight of the most diverse scientific and medical areas and ultimately to the minds of the general public. Overall, four main lines of interest shape the direct influence of microbes on our lives: (i) their relevance for a plethora of infectious diseases, (ii) their participation in symbiotic interactions (in particular in our gut microbiota), (iii) their biotechnological applications and resulting economic impact, and (iv) their emanating role as model organisms for human physiology and pathology.

Infection diseases were the most common causes of death prior to the emergence of antibiotics and the general improvement of sanitation and preventive medicine. As a constant threat to individual health, domesticated animals, and agricultural productivity, microbes were omnipresent in everybody's life and had a deep impact at both the social and economic levels, sometimes with pandemic proportions (cf. the periodic episodes of Black Plague or the Irish Potato Famine). The discovery and study of infectious microbes as well as the consequent implementation of hygienic standards and the application of antibiotic chemotherapy thus were instrumental for the rise of average life expectancy in the $20^{\text {th }}$ century, at least in the Western world. However, microorganisms have resulted to be much more adaptive than previously suspected and have struck back by developing resistance to antibiotics at an everaccelerating pace. Non-restrictive policies regulating antimicrobial chemotherapy, the resulting inflationary use of antibiotics in patient care and animal farming, as well as the increased mobility, have potentiated the development and spread of super-resistant microbial strains. As a result, we are confronted with a situation, in which microbial infections may advance to become the new old challenge for medical research. Only in the USA, for instance, 23,000 people die every year from the direct consequence of infections with antibiotic-resistant bacteria [1]. Especially in developing countries, the risk of bacterial and fungal infections is often comparable to that of diseases mediated by unicellular parasites. For instance, malaria (in 2010: approximately 219 million cases and 660.000 deaths [2]), leishmaniosis (approximately 12 million persons currently infected worldwide with annual casualties in the range of

doi: $10.15698 /$ mic2014.01.118

Received 22.12.2013, Accepted 02.01.2014, Published 6.01.2014.

Keywords: microbes, microbial research, unicellular organism, microbiome, cell death, apoptosis, autophagy, aging, neurodegeneration, 
20.000-30.000 [3]), or trypanosomiasis (estimated 7-8 million and 30.000 cases worldwide for American and African trypanosomiasis, respectively $[4,5])$, all represent major socioeconomic burdens that directly and indirectly take a heavy toll on human life.

Beyond the threat by external microorganisms, we are exposed to and actually depend on our resident microbial population. The gut microbiota is comprised of a broad and dynamic repertoire of microorganisms in which bacteria predominate but Archaea and Eukarya are also present [6]. In fact, our enteric flora can be considered as a virtual organ $[7,8]$ in which the number of microbial cells is approximately ten times larger than the quantity of eukaryotic cells contained in the whole body [9], with important ecological, metabolic and physiological implications. The genetic variability among commensal microbial cells (the microbiome) outnumbers that of the human genome by more than two logs [10]. Also, the metabolic activity of the intestinal microbiota significantly contributes to and largely affects the whole-body metabolism [11]. This tight and intricate host-microbe interplay reflects a symbiotic relationship, in which the microbial commensals contribute to the host's energy harvesting, the defense against infectious threats, as well as to the regulation of the immune system $[12,13]$. Furthermore, internal microbes directly affect inflammatory and neoplastic disease mechanisms, condition our propensity to develop obesity and metabolic syndrome, have a neurobehavioural impact, and influence therapeutic responses including at the level of anticancer treatments [14-21]. Importantly, most of these hostmicrobe interactions remain to be deciphered in their molecular details and many microbial populations contributing to our gut microbiome have yet to be described and characterized. We surmise that microbial research will not only improve our understanding of this complex ecosystem but also explore strategies for exploiting our flora for therapeutic use.

The benefits that we derive from microbial activities reach far beyond the direct cooperative relationship with intestinal microbes. For instance, microorganisms are involved in maintaining the ecological flux, e.g. through recycling vital elements like carbon and nitrogen, as elements at the base of the food chain (particularly in aquatic ecosystems), or as pathogens for population control. Even beyond historic records, mankind has discovered and technically refined the employment of microbial organisms for the production of essential food items like bread or cheese and beverages like beer or wine. This ancient biotechnological use of microorganisms has left a deep, millennium-long social, economic and cultural footprint. In modern biotechnology, genetic engineering of microbes allows for the efficient manufacturing of natural and synthetic products (including multiple drugs and hormones), and industrial microbiology takes advantage of unicellular organisms in large-scale processes such as wastewater treatment or industrial fermentation [22].

The evolutionary conservation of the principal biochemical and cell biological pathways in microbes coupled to their vast technical advantages (from rapid growth to inexpensive accessibility) has made them essential model organisms and basic research tools to explore the fundamental processes of human physiology and pathology. In fact, many crucial mechanisms at the foundation of human cellular processes were first discovered in unicellular organisms, as it is the case for the cell division cycle, elemental cell death pathways, autophagy, vesicular fusion, and mitochondrial biogenesis [23-36]. Furthermore, pathological scenarios central to human health are successfully modeled in unicellular organisms. For instance, it is currently estimated that half of the genes and drugs known today to causally influence aging in multicellular animals are the result of initial studies perfomed in yeast [37-44]. Heterologous expression of human proteins involved in different diseases are instrumental for the causal and molecular understanding of detrimental afflictions such as cancer and neurodegenerative disorders like Parkinson's or Alzheimer's disease [45-48]. Certainly, the use of unicellular organisms with the purpose of modeling molecular mechanisms and disorders in humans demands the subsequent validation of the results in higher eukaryotes. Nevertheless, the high degree of conservation of basic biological processes underscores the immense potential of microbial cells as model organisms that may well explore the fundamental principles of human health and disease.

\section{A UNIVERSALLY ACCESSIBLE PLATFORM FOR HIGH- QUALITY PUBLICATIONS IN THE MICROBIAL FIELD}

MIC approaches this vast thematic heterogeneity by publishing a whole array of peer-reviewed papers, including primary research articles and reports, as well as different formats of review and commentary articles. Given the global impact of microbial research, MIC makes all articles freely available on the Internet to be read, downloaded, stored, printed, copied, and distributed by any interested individual in accordance to the journal's commitment to the principles of open-access publishing. This commitment reflects our conviction that science in general and research in particular are building elements of our modern societies that provide medical and technical improvements as well as cultural, educational and social benefits. Being responsible for generating, conserving and diffusing this public good, the research community needs to make full use of the World Wide Web, for the benefit of both the scholarly and general readership. Indeed, the global access to the Internet has fundamentally changed the way information in general and research literature in particular can be exchanged. In contrast to print publishing - where each transaction from the publisher to the reader involves significant cost - online publishing allows the deposition of a single copy that can be accessed by anyone around the world without (or with little) additional costs. Assessing universal online accessibility to scientific knowledge allows for the quick and unrestricted use of published data by researchers and interested individuals, maximizes the visibility of the authors' works, and promotes the availability of the latest research results for educational purposes. MIC 
authors - who retain full copyright of their work - must therefore agree to make their articles legally available for reuse with no permissions required or fees raised as long as they and the journal are appropriately cited as the original source. By pursuing an open access approach and the universal accessibility to scientific knowledge, we support one of the essential values of science: the free exchange of ideas.

MIC believes that the publication of a research work and the consequent dissemination of results and thoughts among scientists and readers is a fundamental part of doing research. Consequently, any costs generated from publication should be considered as one of the basic expenses to be covered by research grants or by the authors' institutions. However, it remains a fact that due to economic restraints in developing countries, the vast majority of biomedical publications are signed by authors from the financially most potent nations. This also applies to the microbial research field, even though the developing countries often suffer microbiological threats that cost or endanger millions of lives per year. Following these concerns, MIC has implemented a waiver program (DevResearch Program) that - depending on the applicant's situation partly or completely exempts the corresponding authors based in low-income countries from paying publication fees. The goal of this policy is to facilitate and promote scientific authorship from developing countries. Of note, microbial research combines both the possibility to work with affordable model systems and direct medical applicability to microbial-derived health issues. That is why - by means of its DevResearch Program - MIC also intends to promote the implementation of this research field into projects, programs and policies that may contribute to sustainable development at the scientific and social levels.

\section{REFERENCES}

1. Centers for Disease Control and Prevention (2013). Antibiotic resistance threats in the United States, 2013. Available at: http://www.cdc.gov/drugresistance/threat-report-2013/pdf/arthreats-2013-508.pdf [Accessed 20.12.2013].

2. World Health Organization and Global Malaria Programme (2012). World malaria report 2012. World Health Organization, Geneva. Available at: http://www.who.int/features/factfiles/malaria/en/index.html [Accessed 21.12.2013].

3. Leishmaniasis (2013). World Health Organization, Geneva. Available at: http://www.who.int/mediacentre/factsheets/fs375/en/index.html [Accessed 21.12.2013].

4. Chagas disease (American trypanosomiasis) (2013). World Health Organization, Geneva. Available at:

http://www.who.int/mediacentre/factsheets/fs340/en/index.html [Accessed 21 12.2013].

5. WHO | Trypanosomiasis, Human African (sleeping sickness) (2013) World Health Organization, Geneva. Available at: http://www.who.int/mediacentre/factsheets/fs259/en/index.html [Accessed 21.12.2013].

\section{CONCLUDING REMARKS}

Altogether, it is evident that microbial research is enormously heterogeneous with a wide and growing impact on our lives at the academic, economic, and social levels. MIC emerges with the intention to serve as a publishing forum that supports and enfolds this diversity as it provides a unique, high-quality and universally accessible source of information and inspiration. It is time to be or fall in love with microbial research and we are convinced that you will do so through MIC - as a reader or a contributor.

\section{ACKNOWLEDGMENTS}

FM is grateful to the FWF for grants LIPOTOX, I1000, P23490-B12 and P24381-B20.

\section{CONFLICT OF INTEREST}

The authors declare no conflict of interest.

\section{COPYRIGHT}

(C) Carmona-Gutierrez et al. This is an open-access article released under the terms of the Creative Commons Attribution-NonCommercial-NonDerivative 3.0 license, which allows readers to download the article and share it with others, provided that the original authors and source are acknowledged. The article cannot be changed in any way or used commercially.

Please cite this article as: Didac Carmona-Gutierrez, Guido Kroemer and Frank Madeo (2014). One cell, one love: a journal for microbial research. Microbial Cell 1(1): 1-5. doi: 10.15698/mic2014.01.118

6. Rajilić-Stojanović M, Smidt $H$, and de Vos WM (2007). Diversity of the human gastrointestinal tract microbiota revisited. Environ Microbiol 9 (9): 2125-2136.

7. Guarner F and Malagelada J-R (2003). Gut flora in health and disease. The Lancet 361 (9356): 512-519.

8. Shanahan F (2002). The host-microbe interface within the gut. Best Pract Res Clin Gastroenterol 16 (6): 915-931.

9. Bengmark S (1998). Ecological control of the gastrointestinal tract. The role of probiotic flora. Gut 42 (1): 2-7.

10. Bäckhed F, Ley RE, Sonnenburg JL, Peterson DA, and Gordon JI (2005). Host-bacterial mutualism in the human intestine. Science 307 (5717): 1915-1920.

11. Wikoff WR, Anfora AT, Liu J, Schultz PG, Lesley SA, Peters EC, and Siuzdak G (2009). Metabolomics analysis reveals large effects of gut microflora on mammalian blood metabolites. Proc Natl Acad Sci U S A 106 (10): 3698-3703.

12. Dethlefsen L, McFall-Ngai M, and Relman DA (2007). An ecological and evolutionary perspective on human-microbe mutualism and disease. Nature 449 (7164): 811-818. 
13. Honda $\mathrm{K}$ and Littman DR (2012). The microbiome in infectious disease and inflammation. Annu Rev Immunol 30: 759-795.

14. Schwabe RF and Jobin C (2013). The microbiome and cancer. Nat Rev Cancer 13 (11): 800-812.

15. Viaud $S$, Saccheri $F$, Mignot $G$, Yamazaki T, Daillère R, Hannani $D$, Enot DP, Pfirschke C, Engblom C, Pittet MJ, Schlitzer A, Ginhoux F, Apetoh L, Chachaty E, Woerther P-L, Eberl G, Bérard M, Ecobichon C, Clermont D, Bizet C, Gaboriau-Routhiau V, Cerf-Bensussan N, Opolon P, Yessaad N, Vivier E, Ryffel B, Elson CO, Doré J, Kroemer G, Lepage $P$, Boneca IG, Ghiringhelli F, and Zitvogel L (2013). The Intestinal Microbiota Modulates the Anticancer Immune Effects of Cyclophosphamide. Science 342 (6161): 971-976.

16. Plottel CS and Blaser MJ (2011). Microbiome and malignancy. Cell Host Microbe 10 (4): 324-335.

17. Hsiao EY, McBride SW, Hsien S, Sharon G, Hyde ER, McCue T, Codelli JA, Chow J, Reisman SE, Petrosino JF, Patterson PH, and Mazmanian SK (2013). Microbiota Modulate Behavioral and Physiological Abnormalities Associated with Neurodevelopmental Disorders. Cell.

18. Montiel-Castro AJ, González-Cervantes RM, Bravo-Ruiseco G, and Pacheco-López G (2013). The microbiota-gut-brain axis: neurobehavioral correlates, health and sociality. Front Integr Neurosci 7: 70.

19. Bäckhed F, Ding H, Wang T, Hooper LV, Koh GY, Nagy A, Semenkovich CF, and Gordon JI (2004). The gut microbiota as an environmental factor that regulates fat storage. Proc Natl Acad Sci U S A 101 (44): 15718-15723.

20. Vijay-Kumar M, Aitken JD, Carvalho FA, Cullender TC, Mwangi S, Srinivasan S, Sitaraman SV, Knight R, Ley RE, and Gewirtz AT (2010). Metabolic syndrome and altered gut microbiota in mice lacking Tolllike receptor 5. Science 328 (5975): 228-231.

21. Ley RE, Turnbaugh PJ, Klein S, and Gordon Jl (2006). Microbial ecology: human gut microbes associated with obesity. Nature 444 (7122): 1022-1023.

22. Buchholz K and Collins J (2013). The roots-a short history of industrial microbiology and biotechnology. Appl Microbiol Biotechnol 97 (9): 3747-3762.

23. Mizushima N, Levine B, Cuervo AM, and Klionsky DJ (2008). Autophagy fights disease through cellular self-digestion. Nature 451 (7182): 1069-1075.

24. Klionsky DJ and Emr SD (2000). Autophagy as a Regulated Pathway of Cellular Degradation. Science 290 (5497): 1717-1721.

25. Ohsumi Y (2001). Molecular dissection of autophagy: two ubiquitin-like systems. Nat Rev Mol Cell Biol 2 (3): 211-216.

26. Nurse $P$ and Bissett $Y$ (1981). Gene required in $G 1$ for commitment to cell cycle and in $\mathrm{G} 2$ for control of mitosis in fission yeast. Nature 292 (5823): 558-560.

27. Klein F, Mahr P, Galova M, Buonomo SB, Michaelis C, Nairz K, and Nasmyth K (1999). A central role for cohesins in sister chromatid cohesion, formation of axial elements, and recombination during yeast meiosis. Cell 98 (1): 91-103.

28. Neupert W (1997). Protein import into mitochondria. Annu Rev Biochem 66: 863-917.

29. Daum G, Böhni PC, and Schatz G (1982). Import of proteins into mitochondria. Cytochrome b2 and cytochrome c peroxidase are located in the intermembrane space of yeast mitochondria. J Biol Chem 257 (21): 13028-13033.

30. Schmidt O, Pfanner N, and Meisinger C (2010). Mitochondrial protein import: from proteomics to functional mechanisms. Nat Rev Mol Cell Biol 11 (9): 655-667.
31. Novick P, Field C, and Schekman R (1980). Identification of 23 complementation groups required for post-translational events in the yeast secretory pathway. Cell 21 (1): 205-215.

32. Kaiser CA and Schekman R (1990). Distinct sets of SEC genes govern transport vesicle formation and fusion early in the secretory pathway. Cell 61 (4): 723-733.

33. Hartwell LH, Culotti J, and Reid B (1970). Genetic Control of the Cell-Division Cycle in Yeast, I. Detection of Mutants. Proc Natl Acad Sci U S A 66 (2): 352-359.

34. Paulovich AG and Hartwell LH (1995). A checkpoint regulates the rate of progression through $S$ phase in $S$. cerevisiae in response to DNA damage. Cell 82 (5): 841-847.

35. Madeo F, Fröhlich E, and Fröhlich KU (1997). A yeast mutant showing diagnostic markers of early and late apoptosis. J Cell Biol 139 (3): 729-734.

36. Carmona-Gutierrez D, Eisenberg T, Büttner S, Meisinger C, Kroemer G, and Madeo F (2010). Apoptosis in yeast: triggers, pathways, subroutines. Cell Death Differ 17 (5): 763-773.

37. Fabrizio P, Pozza F, Pletcher SD, Gendron CM, and Longo VD (2001). Regulation of longevity and stress resistance by Sch9 in yeast. Science 292 (5515): 288-290.

38. Bonawitz ND, Chatenay-Lapointe M, Pan Y, and Shadel GS (2007). Reduced TOR signaling extends chronological life span via increased respiration and upregulation of mitochondrial gene expression. Cell Metab 5 (4): 265-277.

39. Imai S, Armstrong CM, Kaeberlein M, and Guarente L (2000). Transcriptional silencing and longevity protein Sir2 is an NAD-dependent histone deacetylase. Nature 403 (6771): 795-800.

40. Kaeberlein M, McVey $M$, and Guarente L (1999). The SIR2/3/4 complex and SIR2 alone promote longevity in Saccharomyces cerevisiae by two different mechanisms. Genes Dev 13 (19): 2570-2580.

41. Wei M, Fabrizio P, Hu J, Ge H, Cheng C, Li L, and Longo VD (2008). Life span extension by calorie restriction depends on Rim15 and transcription factors downstream of Ras/PKA, Tor, and Sch9. PLoS Genet 4 (1): e13.

42. Howitz KT, Bitterman KJ, Cohen HY, Lamming DW, Lavu S, Wood JG, Zipkin RE, Chung P, Kisielewski A, Zhang L-L, Scherer B, and Sinclair DA (2003). Small molecule activators of sirtuins extend Saccharomyces cerevisiae lifespan. Nature 425 (6954): 191-196.

43. Van Leeuwen F, Gafken PR, and Gottschling DE (2002). Dot1p modulates silencing in yeast by methylation of the nucleosome core. Cell 109 (6): 745-756.

44. Eisenberg $T$, Knauer $H$, Schauer A, Büttner $S$, Ruckenstuhl C, Carmona-Gutierrez D, Ring J, Schroeder S, Magnes C, Antonacci L, Fussi $\mathrm{H}_{\text {, }}$ Deszcz L, Hartl R, Schraml E, Criollo A, Megalou E, Weiskopf D, Laun P, Heeren G, Breitenbach M, Grubeck-Loebenstein B, Herker E, Fahrenkrog B, Fröhlich K-U, Sinner F, Tavernarakis N, Minois N, Kroemer G, and Madeo F (2009). Induction of autophagy by spermidine promotes longevity. Nat Cell Biol 11 (11): 1305-1314.

45. Cooper AA, Gitler AD, Cashikar A, Haynes CM, Hill KJ, Bhullar B, Liu K, Xu K, Strathearn KE, Liu F, Cao S, Caldwell KA, Caldwell GA, Marsischky G, Kolodner RD, LaBaer J, Rochet J-C, Bonini NM, and Lindquist $S$ (2006). $\alpha$-Synuclein Blocks ER-Golgi Traffic and Rab1 Rescues Neuron Loss in Parkinson's Models. Science 313 (5785): 324-328.

46. Willingham S, Outeiro TF, DeVit MJ, Lindquist SL, and Muchowski PJ (2003). Yeast genes that enhance the toxicity of a mutant huntingtin fragment or alpha-synuclein. Science 302 (5651): 1769-1772. 
47. Büttner S, Habernig L, Broeskamp F, Ruli D, Vögtle FN, Vlachos $M$, Macchi F, Küttner V, Carmona-Gutierrez D, Eisenberg T, Ring J, Markaki M, Taskin AA, Benke S, Ruckenstuhl C, Braun R, Van den Haute $C$, Bammens T, van der Perren A, Fröhlich K-U, Winderickx J, Kroemer G, Baekelandt V, Tavernarakis N, Kovacs GG, Dengjel J, Meisinger C, Sigrist SJ, and Madeo F (2013). Endonuclease $G$ mediates $\alpha$-synuclein cytotoxicity during Parkinson's disease. EMBO J 32 (23): 3041-54.
48. Treusch S, Hamamichi S, Goodman JL, Matlack KES, Chung CY, Baru V, Shulman JM, Parrado A, Bevis BJ, Valastyan JS, Han H, LindhagenPersson M, Reiman EM, Evans DA, Bennett DA, Olofsson A, DeJager PL, Tanzi RE, Caldwell KA, Caldwell GA, and Lindquist $S$ (2011). Functional links between $A \beta$ toxicity, endocytic trafficking, and Alzheimer's disease risk factors in yeast. Science 334 (6060): 1241-1245. 